\title{
REVIEW ON REMOVAL OF HEAVY METALS FROM ACID MINE DRAINAGE
}

\author{
R.W.GAIKWAD $*^{1}-$ D.V.GUPTA ${ }^{2}$ \\ 1 Department of Chemical Engineering, Pravara Rural Engineering College, Loni, Dist: \\ Ahmednagar (MS)-413736 \\ 2 University School of Chemical Technology, GGS Indraprastha University, Kashmere Gate \\ New Delhi-110006
}

(phone: 91-2422-273202; fax: 91-2422-273537)

*Corresponding author

e-mai:lrwgaikwad@yahoo.com

(Received 29 $9^{\text {th }}$ August 2007; accepted 24 ${ }^{\text {th }}$ June 2008)

\begin{abstract}
Acid mine drainage (AMD) is one of the most significant environmental challenges facing the mining industry worldwide. This article summarizes the literature on the removal of heavy metals from acid mine drainage wastewater by various techniques. Investigation has been carried out across the world in order to control and decrease the level of heavy metals as pollutants from acid mine drainage wastewater.
\end{abstract}

Keywords: Treatment, effects, metals, coal mine waste.

\section{Introduction}

Abandoned Mine Drainage (also referred as AMD) is water that has become contaminated as a result of passage through a physical environment created by coal mining activities of the past. This contamination can occur in the underground voids created by deep or underground mining or it can occur by water passing through coal mining refuse left on the surface.

The vast majority of this type of pollution results from old mining operations that have simply been abandoned after the coal was extracted. In some cases, the AMD is from very old mining operations dating from the turn of the 20th century. Prior to 1977, the laws governing coal mining operations were less stringent concerning their environmental impacts. It was a common practice to simply abandon mining operations following the exhaustion of the coal reserve, and then declare bankruptcy. This allowed the mining operators to walk away from liabilities, including environmental devastation.

The nature of AMD contamination varies greatly from site to site, as its formation is dependent on different factors. AMD often lowers water quality and impairs aquatic life, and is most often characterized by one or more of the four major components:

- Low pH (high acidity), i.e., acid mine drainage

- High metal concentrations (iron is the most common)

- Elevated sulfate level

- Excessive suspended solids and/or siltation

The majority of AMD problems result from surface water contact with the unreclaimed waste rock and other earthen materials or from the seepage or drainage of ground water which has contacted the coal or rock strata remaining in an underground mine. If the water becomes acidic, it is referred to as "acid mine drainage". Acid is a 
contaminant of primary concern since it can leach toxic concentrations of metals from rocks at mine sites.

Acids in streams are a problem because they can corrode metal pipes and structures, break down concrete, and kill or stunt plants and other aquatic life-forms. Acidic surface waters or runoff can also break down metallic compounds of iron, sulfur, manganese, and aluminum found in nearby rock or earthen waste piles.

Acid solutions form when surface or ground water comes into contact with acidic material, mostly pyrite, commonly found in mine rocks, earthen refuse piles, or underground mine works and/or auger holes. The iron-sulfide mineral pyrite is often found near subsurface coal seams along with compounds containing manganese, aluminum, and other metals. In the presence of oxygen, ordinary rain water or ground water can react with the sulfur to form sulfuric acid.

Acid concentrations in AMD can reach levels that are more than 10,000 times higher than neutral waters, presenting a powerful leaching agent that can dissolve significant amounts of metal compounds and leach additional acid from rocks and earthen wastes commonly found at most mine sites.

Layers of rock and earth above the coal removed during mining commonly contain traces of iron, manganese, and aluminum and can also contain other heavy metals. These metals can be dissolved from mining sites through the action of acid runoff, as described above, or can be washed into streams as sediment. Many metals, though common, can be toxic to fish and other aquatic organisms when they are present in high dissolved concentrations. Dissolved iron and iron precipitate, for example, can kill the aquatic biota that fish feed on, thus reducing the overall fish population. Iron precipitate can also clog the gill structures of fish which will eventually lead to their death as well. In addition, precipitation of iron in the stream channel can also wipe out the aquatic food chains and adversely affect fish populations.

As pyrite wastes are chemically broken down, a sulfate compound is produced in runoff waters. Sulfates can bond with water molecules to form sulfuric acid or can attach to calcium atoms to form gypsum sludge. Elevated sulfate levels are often found in AMD discharges.

Most people think contaminated AMD results from chemical reactions in streams, but a significant threat to water quality and aquatic organisms comes from eroding soils at abandoned mining sites. Tiny fly nymphs, insect larvae, and other organisms that form the base of aquatic food chains can be wiped out by heavy accumulations of soil and mine waste particles that wash into streams after rain events. Suspended silt particles can clog the gills of fish and smother eggs on the stream bottom. Streams and rivers muddied by silt and other suspended solids also mean higher costs at municipal and industrial water treatment plants and accelerated sedimentation in reservoirs.

Acid mine drainage (AMD) is a common problem at thousands of abandoned mine sites all over the world. The combination of low $\mathrm{pH}$ and high concentrations of metals associated with mine drainage can have severe toxicological effects on aquatic ecosystems. Acute exposure to high concentrations of metals can kill organisms directly, while long-term exposure to lower can cause mortality or other effects such as stunted growth, lower reproduction rates, deformities and lesions (Lewis and Clark, 1996). 
AMD is caused by the weathering of minerals such as iron disulphide (FeS2), commonly known as pyrite, by water and oxygen (Singer and Stumm, 1970). When pyrite is exposed to water and oxygen, oxidation and hydrolysis reactions produce sulfuric acid (H2SO4) and free hydrogen ions $(\mathrm{H}+)$, acidifying the water. Lower acidities allow other metals which are associated with mining, such as cadmium, copper, lead and zinc, to enter the solution phase and be transported from the system (Stumm et al., 1996). These metals precipitate from the water column as $\mathrm{pH}$ increases, however the $\mathrm{pH}$ at which there is a potential for complete precipitation varies for different metals. For example, zinc precipitates at a minimum $\mathrm{pH}$ of 8.4 (Stumm et al., 1996). Transport of zinc can occur over long distances, since the $\mathrm{pH}$ of many streams is less than 8.0. The rate of the AMD weathering reactions is limited by the surface area of ferrous iron exposed to weathering (Gray, 1997). The process of extracting ore from underground veins alters hydrologic processes by creating new pathways. As a result of mining activities, water and oxygen are able to infiltrate areas of high metal-sulfide mineral content at an increased rate, accelerating the natural acid-producing weathering processes.

\section{Heavy metal pollution}

There are many elements presents on the earth's crust. $\mathrm{H}, \mathrm{C}, \mathrm{N}, \mathrm{O}, \mathrm{Na}, \mathrm{Mg}, \mathrm{P}, \mathrm{S}, \mathrm{Cl}$, $\mathrm{K}, \mathrm{Ca}$, constitute $99.9 \%$ of all living matter. In addition 14 elements viz. B, F, Si, V, Cr, $\mathrm{Mn}, \mathrm{Fe}, \mathrm{Co}, \mathrm{Cu}, \mathrm{Sc}, \mathrm{Mo}, \mathrm{Sn}$ and $\mathrm{l}$ are the essential elements. Metals like $\mathrm{Hg}, \mathrm{Pb}, \mathrm{Cd}, \mathrm{As}$, $\mathrm{Cr}, \mathrm{Zn}, \mathrm{Cu}, \mathrm{Mn}$ which are not essential but when present in aquatic environment are hazardous.

Although heavy metals are natural components of the environment but when their concentrations increase more than normal levels they become potentially hazardous. The examples include diseases like itai-itai disease, mancigata (Diospyros melanoxylon) and lead poisoning. Hence the task of the environmental scientist is to regulate their influx into the environment in biologically assumable forms and acceptable levels.

There are two broad classes of methodologies used to treat Acid Mine Drainage:

Passive Treatment: natural chemical and biological reactions occuring in a controlled microbiological-chemical reactor without powered mechanical assistance (most of the time).

Active Treatment: mechanical addition of alkaline chemicals to raise $\mathrm{pH}$ and precipitate metals.

This paper is a comparative study of these methods to remove heavy metals from Acid Mine Drainage.

B-W. Zhang et al. (1993) prepared amidoxime-containing modified starch by reaction of acrylonitrile with cross linked starch, catalyzed by ceric ions, and subsequent derivatization with free hydroxylamine in methanol. The early investigations of this new cation exchange material revealed that the maximum capacities of the modified starch for the heavy metal ions $\mathrm{Cu} 2+, \mathrm{Hg} \mathrm{2+}, \mathrm{Pb} \mathrm{2+}$ and $\mathrm{Zn}$ $2+$ were $1.86,0.59,0.52$ and $0.37 \mathrm{mmol}$ g- 1 (dry weight), respectively. At pH 5, the order of decreasing selectivity of the cation exchanger for the various metal ions was: $\mathrm{Hg} 2+>\mathrm{Cu} 2+>\mathrm{pb} 2+>\mathrm{Zn} 2+>\mathrm{Ni} 2+>\mathrm{Cr} 3+$. The product could be reused after 
regeneration with diluted hydrochloric acid. The high exchange capacity for copper was fully examined because of the possible industrial application.

Yi-Min Gao et al. (1995) identified and studied a new hybrid iron-rich inorganic sorbent in relation with heavy metal removals in fixed-bed processes for influent $\mathrm{pH}$ as low as 3.5. Every single particle of this new hybrid sorbent essentially contains ferrihydrite along with a crystalline silicate phase, akermanite, in close proximity (in the order of $100 \mathrm{~A}^{\mathrm{O}}$ ) to one another. Akermanite has a unique ability to produce hydroxyl ions through incongruent hydrolysis reactions without being washed out from the fixed bed. The simultaneous presence of akermanite and ferrihydrite in a single particle has a synergistic effect on the sorption process: while akermanite helps neutralize aqueousphase hydrogen ions (thus enhancing sorption capacity of ferrihydrites), neighboring sorption sites in ferrihydrites quickly remove dissolved heavy metals, thus avoiding precipitation. Equally important, the hybrid sorbent can be regenerated with any amine/ammoniacal solution and reused for multiple number of cycles. Some precipitations may occur within the column at relatively high influent concentrations of heavy metals (around $50 \mathrm{mg} / 1$ ) or due to chromatographic effect. Such precipitates are, however, amenable to removals by conventional backwashing.

Jack Z. Xie et al. (1996) prepared Biosorbents and chemically modified them, then compared with commercial ion-exchange resins to determine their metal-binding capacity, the range of metals bound, the effects of $\mathrm{pH}$, temperature, contact time, interference by common salts and the effect of multiple cycles of metal binding and elution. Biosorbents were prepared from microorganisms isolated from pristine and metal impacted (acid mine drainage) environments and included heterotrophs, methanotrophs, algae, sulfate reducers, and exopolysaccharide- producing cultures. The chemical modifications examined included encapsulation in polysulfone resin, acid, alkali, carbon disulfide, phosphorus oxychloride, anhydrous formamide, sodium thiosulfate, sodium chloroacetic acid, and phenysulfonate treatments. A culture isolated from an acid mine drainage impacted site, IGTM17, produced biosorbent material with about three-fold higher metal-binding capacity than other biosorbents examined in this study.

Teruyuki Umita (1996) studied the Drainage from sulfur mines contains a high concentration of ferrous iron. The mechanism of acid mine drainage formation was briefly explained. As a case study, successful measures taken at the abandoned Matsuo mine, Iwate Prefecture, Japan, for preventing the pollution in receiving rivers was presented in this paper. The measures consisted of the construction works against pollution sources and the construction of a drainage treatment plant in which Thiobacillus ferrooxidans oxidizes ferrous iron under a low $\mathrm{pH}$ condition, and produced ferric iron is removed by sedimentation. Then, a laboratory-scale fluidized bed reactor using anion exchange resin as attaching material for the bacteria was examined in order to improve the efficiency of biological oxidation of ferrous iron. More than $90 \%$ of oxidation had been maintained for 2 months at $1 \mathrm{~h}$ of HRT, which suggests that the size of the oxidation tank could be reduced.

P.D. Rose et al. (1998) investigated that acid mine drainage pollution may be associated with large water volume flows and exceptionally long periods of time over which the drainage may require treatment. While the use and role of sulfate reducing bacteria has been demonstrated in active treatment systems for acid mine drainage remediation, reactor size requirement and the cost and availability of the carbon and electron donor source are factors which constrain process development. Little attention 
has focused on the use of waste stabilization pounding processes for acid mine drainage treatment. Wastewater pounding is a mature technology for the treatment of large water volumes and its use as a basis for appropriate reactor design for acid mine drainage treatment is described including high rates of sulfate reduction and the precipitation of metal sulfides. Together with the co-disposal of organic wastes, algal biomass is generated as an independent carbon source for SRB production. Treatment of tannery effluent in a custom-designed high rate algal pounding process, and its use as a carbon source in the generation and precipitation of metal sulfides has been demonstrated through piloting to the implementation of a full-scale process. The treatment of both mine drainage and zinc refinery wastewaters is reported. A complementary role for micro algal production in the generation of alkalinity and bioadsorptive removal of metals has been utilized and an Integrated 'Algal Sufhate Reducing Pounding Process for the Treatment of Acidic and Metal Wastewaters' (ASPAM) has been described.

Young-Wook Cheong et al. (1998) designed, operated and then evaluated a pilot reactor system for testing acid mine drainage treatment. at the Dalsung mine, for operating problems. Field analyses of $\mathrm{pH}$ and Eh (redox potential) were made. In the laboratory, analyses were made of $\mathrm{Cd}, \mathrm{Pb}, \mathrm{As}, \mathrm{Zn}, \mathrm{Cu}, \mathrm{Fe}, \mathrm{Al}$ and $\mathrm{Mn}$. The reactor, containing a mixture of rice stalks, cow manure, and limestone, initially showed decreases of $98 \% \mathrm{Cu}, 100 \% \mathrm{Zn}, 99 \% \mathrm{Fe}, 100 \% \mathrm{Cd}, 97 \% \mathrm{Al}, 61 \% \mathrm{Mn}$ and $100 \% \mathrm{~Pb}$ when the effluents from the reactor had a $\mathrm{pH}$ of 6 and an Eh of about $300 \mathrm{mV}$. However, as time passed, the Eh rose and the amount of metals removed decreased, except Al. This indicated that maintaining reducing conditions was very important for continued metal removal. During the operating period, there were some problems such as a volume change in the substrate within the reactor and scaling on pipes. These problems appeared to reduce the flow of mine drainage in pipes and the reactor over time.

Phillip Elliott et al. (1998) developed a system for the remediation of acid mine drainage using sulfate-reducing bacteria. An up flow porous medium bioreactor was inoculated with sulfate-reducing bacteria (SRB) and operated under acidic conditions. The reactor was operated under continuous flow and was shown to be capable of sulfate reduction at $\mathrm{pH} 4.5,4.0,3.5$ and 3.25 in a medium containing $16.1 \mathrm{mM}$ sodium lactate. This contrasted a previously published work which showed that, at $\mathrm{pH} 3.8$, organic acid concentrations higher than $5 \mathrm{mM}$ completely inhibited biological sulfate reduction. At $\mathrm{pH} 3.25$ the reactor removed $38.3 \%$ of influent sulfate and raised the $\mathrm{pH}$ of the medium to 5.82. The lactate carbon source was exhausted under these conditions. At $\mathrm{pH} 3.0$, sulfide production was below detectable levels, and sulfate removal fell to $14.4 \%$. However, viable SRB were recovered from the column after 21 days of operation at $\mathrm{pH}$ 3.0, indicating that SRB are able to withstand $\mathrm{pH} 3.0$ for extended periods. As a conclusion, we can state that an SRB process would be a viable method of remediating AMD.

Carl S. Kirby et al. (1998) developed a gravity-fed, battery-powered, portable continuously-stirred tank reactor to directly measure aqueous reaction rates in the field. Dye and tracer experiments indicate the reactor is well-mixed. Rates of Fe2+ oxidation at untreated and passively treated coal mine drainage sites in Pennsylvania were measured under ambient conditions and with the addition of either $\mathrm{O} 2$ gas or $\mathrm{NaOH}$ solutions. Uncertainties in rates ranged from $70 \%$ near the lower limit of measurement to as little as $1 \%$ at higher rates of reaction. Multiple linear regressions showed no universal correlations of rates to $\mathrm{Fe} 2+$, dissolved $\mathrm{O} 2$, and $\mathrm{pH}$ (Thiobacillus populations 
were not measured), although data for two more acidic sites were found to fit well for the model $\log$ rate $=\log \mathrm{K}+\mathrm{a} \log [\mathrm{Fe} 2+]+\mathrm{b} \log [\mathrm{OH}-]+\mathrm{c} \log [\mathrm{O} 2]$. Field rates of $\mathrm{Fe}$ oxidation from this and other studies vary by 4 orders of magnitude. A model using the ambient field rate of $\mathrm{Fe}$ oxidation from this study successfully reproduced independently-measured $\mathrm{Fe} 2+$ concentrations observed in a passive wetland treatment facility.

T. K. Tsukamoto et al. (1999) revealed that the Sulfate reducing passive bioreactors are increasingly being used to remove metals and raise the $\mathrm{pH}$ of acidic waste streams from abandoned mines. These systems commonly use a variety of organic substrates (i.e. manure, wood chips) for sulfate reduction. The effectiveness of these systems decreases as easily accessible reducing equivalents are consumed in the substrate through microbial activity. Using column studies at room temperature $\left(23-26^{\circ} \mathrm{C}\right)$, we investigated the addition of lactate and methanol to a depleted manure substrate as a method to reactivate a bioreactor that had lost $>95 \%$ of sulfate reduction activity. A preliminary experiment compared sulfate removal in gravity fed, flow through bioreactors in which similar masses of each substrate were added to the influent solution. Addition of $148 \mathrm{mg} / \mathrm{l}$ lactate resulted in a $69 \%$ reduction in sulfate concentration from 300 to $92 \mathrm{mg} / \mathrm{l}$, while addition of $144 \mathrm{mg} / \mathrm{l}$ methanol resulted in an $88 \%$ reduction in sulfate concentration from 300 to $36 \mathrm{mg} / \mathrm{l}$. Because methanol was found to be an effective sulfate reducing substrate, it was chosen for further experiments due to its inherent physical properties (cost, low freezing point and low viscosity liquid) that make it a superior substrate for remote, high elevation sites where freezing temperatures would hamper the use of aqueous solutions. In these column studies, water containing sulfate and ferrous iron was gravity-fed through the bioreactor columns, along with predetermined methanol concentrations containing reducing equivalents to remove $54 \%$ of the sulfate. Following an acclimation period for the columns, sulfate concentrations were reduced from of $900 \mathrm{mg} / \mathrm{l}$ in the influent to $454 \mathrm{mg} / \mathrm{l}$ in the effluent that reflects a $93 \%$ efficiency of electrons from the donor to the terminal electron acceptor. Iron concentrations were reduced from 100 to $2 \mathrm{mg} / \mathrm{l}$ and the $\mathrm{pH}$ increased nearly 2 units.

E.I. Robbins et al. (1999) evaluated the processes affecting neutralization of acidic coal mine drainage within 'anoxic' limestone drains (ALDs). Influents had $\mathrm{pH} 3.5$ and 2 $\mathrm{mg} / \mathrm{l}$ dissolved oxygen. Even though effluents were near neutral ( $\mathrm{pH} 6$ and alkalinity, acidity), two of the four ALDs were failing due to clogging. Mineral-saturation indices indicated the potential for dissolution of calcite and gypsum, and precipitation of Al31 and Fe31 compounds. Cleavage mounts of calcite and gypsum that were suspended within the ALDs and later examined microscopically showed dissolution features despite coatings by numerous bacteria, biofilms, and $\mathrm{Fe}-\mathrm{Al}-\mathrm{Si}$ precipitates. In the drain exhibiting the greatest flow reduction, Al-hydroxysulfates had accumulated on limestone surfaces and calcite etch points, thus causing the decline in transmissivity and dissolution. Therefore, where Al loadings are high and flow rates are low, a pretreatment step is indicated to promote $\mathrm{Al}$ removal before diverting acidic mine water into alkalinity-producing materials.

D. Feng et al. (2000) characterized and treated Acid mine water from a South African gold mine by the precipitation of heavy metals with lime and sulfides, followed by ion exchange. The novelty of the proposed process lies in the use of carrier magnetic materials for more effective separation of water and solids, as well as the oxidation pretreatment that is also used to sterilize the water. The process can generate vet), pure 
water from acid mine water with a great flexibility and an acceptable cost. The oxidation anti precipitation of heavy metals with lime and subsequent sulfide-carrier magnetic separation appeared to be particularly suitable for the removal of heavy metal ions from the effluent of the particular gold mine that was investigated. The cation exchange resin IR120 can be used to reduce the salinity of the effluent of mine water after removal of heavy metals by precipitation. Low cost sulfuric acid can be used as the cation resin regenerator. The anion exchange resin A375 could reduce the anions (sulfate, chloride, bromide and fluoride) to acceptably low levels in the mine water after precipitation of heavy metals. A combination of sodium hydroxide and saturated lime solution can be used as the anion resin regenerator. A mixture of acidic gypsum from the cation elution section and alkaline gypsum from the anion elution section could generate high quality gypsum as by-product, which could be sold as a valuable raw material to the gypsum industry, to offset process cost. Although these experiments were conducted on the acid mine water of a specific mine, the process could be extended to other mine waters contaminated with heavy metals and high salinities.

Vivek Utgikar et al. (2000) states that biosorption is a potentially attractive technology for treatment of acid mine drainage for separation/recovery of metal ions and mitigation of their toxicity to sulfate reducing bacteria. This study describes the equilibrium biosorption of $\mathrm{Zn}$ (II) and $\mathrm{Cu}$ (II) by nonviable activated sludge in a packed column adsorber. The $\mathrm{Zn}$ (II) uptake capacity of unconditioned sludge (not subjected to processing other than drying) was found to decrease in repeated adsorption-desorption cycles, declining by a factor greater than 20 from cycle 1 to cycle 6 . Equilibrium uptake of metals by dried sludge conditioned by exposure to deionized water at a $\mathrm{pH}$ corresponding to that of the feed solution showed a strong $\mathrm{pH}$ dependence and was modeled using the Langmuir adsorption isotherm. Equilibrium metal uptakes from solutions containing single metal ion were $2.5 \mathrm{mg} \mathrm{g}$ (dry biomass) ${ }^{-1}$ and $3.4 \mathrm{mg}$ g(dry biomass) ${ }^{-1}$ for $\mathrm{Zn}(\mathrm{II})$, and $1.9 \mathrm{mg} \mathrm{g}$ (dry biomass) ${ }^{-1}$ and $5.9 \mathrm{mg} \mathrm{g}$ (dry biomass) ${ }^{-1}$ for $\mathrm{Cu}(\mathrm{II})$ at $\mathrm{pH} 3.0$ and 3.8, respectively. Equilibrium uptakes from binary mixtures were $30 \%$ lower than single component solution uptakes for both metals, indicating some competition between the two metals. No hysteresis was detected between adsorption and desorption equilibriums. Anion concentration and $\mathrm{pH}$ measurements indicated that simultaneous sorption of metal cation and sulfate anion was probably occurring at $\mathrm{pH}$ 3.0, while proton exchange predominated at $\mathrm{pH} 3.8$. Results of the study point to the usefulness of non-viable activated sludge as a biosorbent for recovery/separation of metal ions from acid mine drainages.

Seop Chang et al. (2000) tested organic waste materials as the electron donors for sulfate reducers in treating acid mine drainage. They are oak chips (OC), spent oak from shiitake farms (SOS), spent mushroom compost (SMC), sludge from a wastepaper recycling plant (SWP) and organic-rich soil (ORS). The materials were placed in column reactors, which were inoculated by anaerobic digester fluid. The number of sulfate-reducers increased to $108 \pm 109$ cells $/ \mathrm{ml}$ in 2 weeks in the reactors. The reactors were continuously fed with simulated mine drainage for 35 weeks to determine sulfate reduction and metal removal. SOS, SMC and SWP served well than electron donors than OC and ORS. Metal removal efficiency of the reactor with OC was lower than those with SOS, SMC and SWP at the beginning, but became comparable at a later stage. The solvent extractable of OC inhibited the growth of sulfate reducers. Cellulose polysaccharides were the main components of the waste materials consumed in the reactors. 
Matthew M. Matlock et al. (2002) developed 1,3-benzenediamidoethanethiol dianion (BDET, known commercially as MetX) to selectively and irreversibly bind soft heavy metals from aqueous solution. In the present study BDET was found to remove $>90 \%$ of several toxic or problematic metals from AMD samples taken from an abandoned mine in Pikeville, Kentucky. The concentrations of metals such as iron, may be reduced at $\mathrm{pH}$ 4.5 from $194 \mathrm{ppm}$ to below $0.009 \mathrm{ppm}$. The formation of stoichiomietric BDET-metal precipitates in this process was confirmed using X-ray powder diffraction (XRD), proton nuclear magnetic resonance (1H NMR), and infrared spectroscopy (IR).

Hyun-Joon Lal et al. (2003) studied three laboratory-scales, up flow anaerobic reactors were operated for about $250 \mathrm{~d}$ to determine the effect of activated granular sludge with high density of sulfate reducing bacteria in the treatment of artificial acid mine drainage. Sulfate reducing bacteria in the granular sludge taken from the up flow anaerobic sludge blanket reactor were $1-2 \times 106$ c.f.u. $\mathrm{g}^{-1}$, which is at least 10 times higher than that of organic substrates such as cow manure and oak compost. The reactors with granular sludge effectively removed over $99 \%$ of heavy metals, such as $\mathrm{Fe}, \mathrm{Al}, \mathrm{Cu}$, and $\mathrm{Cd}$ during the experiment. This result suggests a feasibility of the application of granular sludge as a source of sulfate reducing bacteria for the treatment of acid mine drainage.

M.M.G. Chartrand et al. (2003) reveled that acid mine drainage (AMD), which has long been a significant environmental problem, results from the microbial oxidation of iron pyrite in the presence of water and air, affording an acidic solution that contains toxic metal ions. Electrochemical treatment of AMD offers possible advantages in terms of operating costs and the opportunity to recover metals, along with cathodic reduction of protons to elemental hydrogen. This work describes the electrolysis of synthetic AMD solutions containing iron, copper and nickel and mixtures of these metals using a flow-through cell divided with an ion exchange membrane. Iron was successfully removed from a synthetic AMD solution composed of $\mathrm{FeSO} 4 / \mathrm{H} 2 \mathrm{SO} 4$ via $\mathrm{Fe}(\mathrm{OH}) 3$ precipitation outside the electrochemical cell by sparging the electrolyzed catholyte with air. The work was extended to acidic solutions of Fe $2 \mathrm{p}, \mathrm{Cu} 2 \mathrm{p}$, and $\mathrm{Ni} 2 \mathrm{p}$, both singly and in combination, and to an authentic AMD sample containing principally iron and nickel.

T.K. Tsukamoto et al. (2004) states that the lifetime of traditional sulfate-reducing bacteria (SRB) bioreactors that utilize a source of reducing equivalents contained within the matrix (e.g. manure) is limited by the amount of readily available reducing equivalents within that matrix. In order to extend bioreactor lifetime indefinitely, the addition of known concentrations of alternative reducing equivalents (methanol and ethanol) to a depleted matrix was tested at low $\mathrm{pH}$ and low temperatures. Following acclimation, up to $100 \%$ efficiencies of reducing equivalents were directed toward sulfate reduction. Alcohol was added in stoichiometric concentrations to remove $50 \%$ of the added sulfate $(900 \mathrm{mg} / \mathrm{L})$, producing sufficient sulfide to precipitate all of the iron from solution. An average of $42 \%$ of the sulfate was removed following acclimation, reflecting $84 \%$ efficiency. An average of $93 \%$ of the iron was removed $(93 \mathrm{mg} / \mathrm{L})$. Bacteria acclimated to ethanol more rapidly than methanol, although both alcohols were effective as carbon sources. Efficient treatment was observed at the lowest temperatures $\left(6^{\circ} \mathrm{C}\right)$ and lowest $\mathrm{pHs}(\mathrm{pH}=2.5)$ tested. The use of ethanol-fed, highly permeable bioreactor matrices of wood chip, pulverized plastic and rock was also examined to determine which of these porous matrices could be implemented in a field bioreactor. Results indicated that $>95 \%$ of the $100 \mathrm{mg} / \mathrm{L}$ iron added was removed by all matrices. 
Sufficient reducing equivalents were added to remove $450 \mathrm{mg} / \mathrm{L}$ of sulfate, wood and rock matrices removed B350 mg/L plastic removed B225 mg/L. A study comparing rock size indicated that small rocks removed iron and sulfate more efficiently than medium- and large-size rocks. The results suggest that wood and rock in conjunction with ethanol are viable alternatives to traditional bioreactor matrices. These findings have direct application to semi-passive sustained operation of SRB bioreactors for treatment of acidic drainage at remote sites.

E. Erdem et al. (2004) studied the adsorption behavior of natural (clinoptilolite) zeolites with respect to $\mathrm{Co} 2+, \mathrm{Cu} 2+, \mathrm{Zn} 2+$, and $\mathrm{Mn} 2+$ in order to consider its application to purity metal finishing wastewaters. The batch method has been employed, using metal concentrations in solution ranging from 100 to $400 \mathrm{mg} / \mathrm{l}$. The percentage adsorption and distribution coefficients $(K \mathrm{~d})$ were determined for the adsorption system as a function of sorbate concentration. In the ion exchange evaluation part of the study, it is determined that in every concentration range, adsorption ratios of clinoptilolite metal cations match to Langmuir, Freundlich, and Dubinin-Kaganer-Radushkevich (DKR) adsorption isotherm data, adding to that every cation exchange capacity metals has been calculated. It was found that the adsorption phenomena depend on charge density and hydrated ion diameter. According to the equilibrium studies, the selectivity sequence can be given as

$\mathrm{Co} 2+>\mathrm{Cu} 2+>\mathrm{Zn} 2+>\mathrm{Mn} 2+$. These results show that natural zeolites hold great potential to remove cationic heavy metal species from industrial wastewater.

M. C. Costa et al. (2005) found that the acid mine drainage (AMD) is a serious environmental problem resulting from extensive sulfide mining activities. The old copper mine of S. Domingos in Southeast Portugal is an example of such a situation. The abandoned open-pit from the mining operations resulted in the creation of a large pit lake with acidic water $(\mathrm{pH}-2)$ and high contents of sulfate and heavy metals. Sulfate reducing biological processes have been studied as a remediation technology for this problem. A new application based on a simple and semi-continuous process for the treatment of S. Domingos AMD has been presented herein. Experiments using bench scale fixed-bed column bioreactors were carried out to evaluate the efficiency of the process. Sewage, anaerobic sludge and soil from the mining area were tested as solid matrices and/or inocula, as well as sources of complex organic substrates. The addition of lactose as a supplementary carbon source, easily available at zero cost or at negative cost in the effluents of the local cheese industries, was also tested. The data obtained indicate that it is possible to use the matrices tested for the production of sulfide by sulfate reduction, and that the regular addition of lactose is effective. Results showed that the process is efficient for the precipitation of the main dissolved metals, for the reduction in the sulfate content and, most importantly, for the neutralization of the AMD. Moreover, the use of soil as solid support also showed the possibility of using this process for the decontamination of both waters and soils.

Louis R. Bernier (2005) assessed the efficiency of serpentinite as an alternative alkalinity generating material for the passive treatment of acid mine drainage (AMD). Three series of batch experiments were designed for the passive treatment of a low $\mathrm{pH}$ (1.6) AMD synthetic solution containing 2,500 ppm Fe2+, 6,600 ppm SO4 2), 10.5 ppm $\mathrm{Al}, 15 \mathrm{ppm} \mathrm{Ni}$, and traces of $\mathrm{Cr}, \mathrm{Mn}$ and $\mathrm{Cu}$. The influencing factors studied were: the effect of water/rock ratio, residence time, type of the alkalinity generating material (dolomite, magnesite, marble, serpentinite), and nature of the system (open vs. closed cells). The variations in solution chemistry observed in the open cells indicate that a 
lower water/rock ratio $(0.33 \mathrm{ml} / \mathrm{g})$ was the most efficient for metals removal. The optimal residence time in open cells was $24 \mathrm{~h}$ to reach the higher $\mathrm{pH}$ values. In the closed cells laboratory setup, synthetic AMD was placed in contact with the various alkaline materials for three different contact times $(24,48,72 \mathrm{~h})$. The optimal $\mathrm{pH}$ was reached after $48 \mathrm{~h}$ and did not change appreciably for longer contact time, and the best results for metal removals were obtained with marble and serpentinite. Single treatment efficiency was compared with a successive treatment approach. The most promising results were obtained with a five step treatment: (1) pre-treatment in a closed cell using serpentinite, (2) aeration and settling, (3) treatment in an open cell using marble, (4) final aeration and settling, and (5) filtration with a coarse silica sand. With this configuration, the final $\mathrm{pH}$ was 6.5 and pronounced metals depletion was achieved ( $100 \%$ for $\mathrm{Al}, 99.95 \%$ for $\mathrm{Fe}, 85.7 \%$ for $\mathrm{Ni}$ ).

Xinchao Wei et al. (2005) studied that the large volumes of sludge produced through the active treatment of acid mine drainage (AMD) require further processing and final disposal. AMD sludge typically contains a heterogeneous mixture of iron, aluminum, magnesium, and calcium oxides/hydroxides that are of little to no practical value. However, purified iron and aluminum hydroxides have potential commercial value. Based on the solubility of the major dissolved metals, a two-step selective precipitation process was developed to recover high purity iron and aluminum as separate hydroxide products through the manipulation of current AMD treatment operations. The recommended $\mathrm{pH}$ for iron precipitation was $\mathrm{pH} 3.5-4.0$ with precipitate purity $>93.4 \%$ and iron recovery $>98.6 \%$. AMD water after iron removal was used as source water for aluminum recovery. Aluminum precipitated best at $\mathrm{pH}$ 6.0-7.0 with aluminum recovery $>97.2 \%$ and precipitate purity $>92.1 \%$.

Jacco L. Huisman et al. (2006) investigated that one of the best available technologies for the removal of metals from water is in the form of metal sulfides. Metal removal by sulfide precipitation is a well-known process that is characterized by compact residues and very high removal efficiencies. Compared to neutralization alone the sludge volume is 6 to 10 times lower and the toxic metals are removed to a $0.01-1$ ppm level. Furthermore, selective metal precipitation is possible, allowing for separate recovery of valuable metals like copper, nickel, cobalt and zinc from nuisance metals like arsenic and antimony. However, the cost of reagent (NaHS or H2S gas) and safety aspects are often prohibitive. This paper describes a novel biological process for safe and cost effective production of sulfide from elemental sulfur, waste sulfuric acid or sulphate present in effluents. With this technology, gaseous or dissolved H2S is produced on-site and on-demand in an engineered, high rate bioreactor Experience with industrial applications at metal processing plants will be presented. The technology can serve to selectively recover metals from e.g. bleed streams, leach liquor, effluent streams and acid mine drainage. Lower overall costs and increased safety (no transport or storage of sulfide, production on-demand and at ambient pressure) are the main advantages of this new process compared to its alternatives.

Gerald J. Zagury et al. (2006) found that acid mine drainage (AMD), which contains high concentrations of sulfate and dissolved metals, is a serious environmental problem. It can be treated in situ by sulfate reducing bacteria (SRB), but effectiveness of the treatment process depends on the organic substrate chosen to supply the bacteria's carbon source. Six natural organic materials were characterized in order to investigate how well these promote sulfate reduction and metal precipitation by SRB. Maple wood chips, sphagnum peat moss, leaf compost, conifer compost, poultry manure and conifer 
sawdust were investigated in terms of their carbon (TOC, TIC, DOC) and nitrogen (TKN) content, as well as their easily available substances content (EAS). Single substrates, ethanol, a mixture of leaf compost $(30 \% \mathrm{w} / \mathrm{w})$, poultry manure $(18 \% \mathrm{w} / \mathrm{w})$, and maple wood chips $(2 \% \mathrm{w} / \mathrm{w})$, and the same mixture spiked with formaldehyde were then tested in a 70-day batch experiment to evaluate their performance in sulfate reduction and metal removal from synthetic AMD. Metal removal efficiency in batch reactors was as high as $100 \%$ for $\mathrm{Fe}, 99 \%$ for $\mathrm{Mn}, 99 \%$ for $\mathrm{Cd}, 99 \%$ for $\mathrm{Ni}$, and $94 \%$ for Zn depending on reactive mixtures. Early metal removal (0-12 d) was attributed to the precipitation of (oxy) hydroxides and carbonate minerals. The lowest metal and sulfate removal efficiency was found in the reactor containing poultry manure as the single carbon source despite its high DOC and EAS content. The mixture of organic materials was most effective in promoting sulfate reduction, followed by ethanol and maple wood chips, and single natural organic substrates generally showed low reactivity. Formaldehyde $(0.015 \%(\mathrm{w} / \mathrm{v}))$ provided only temporary bacterial inhibition. Although characterization of substrates on an individual basis provided insight on their chemical make-up, it did not give a clear indication of their ability to promote sulfate reduction and metal removal.

The summary of the above literature is given in the Table 1.

Table 1. Summary of literature

\begin{tabular}{|c|c|c|c|c|c|c|c|}
\hline S.N. & $\begin{array}{l}\text { Method of } \\
\text { Removal of } \\
\text { heavy metal }\end{array}$ & Metal & $\mathbf{p H}$ & $\begin{array}{l}\text { Concent- } \\
\text { ration }\end{array}$ & $\begin{array}{c}\% \\
\text { Removal }\end{array}$ & Data & $\begin{array}{l}\text { Authors } \\
\text { Name }\end{array}$ \\
\hline 1 & $\begin{array}{l}\text { Amidoxime- } \\
\text { containing } \\
\text { modified starch } \\
\text { cation } \\
\text { exchange } \\
\text { method }\end{array}$ & $\begin{array}{l}\mathrm{Cu} \\
\mathrm{Hg} \\
\mathrm{Pb} \\
\mathrm{Zn}\end{array}$ & 5 & $\begin{array}{l}100-200 \\
\mathrm{mg} / \mathrm{l}\end{array}$ & ----- & $\begin{array}{l}\text { Distribution } \\
\text { coefficients }\end{array}$ & $\begin{array}{l}\text { B.W. Zhang } \\
\text { et al. (1993) }\end{array}$ \\
\hline \multicolumn{8}{|c|}{$\begin{array}{l}\text { Remarks } \\
\text { Modified starch could acquire wide application in purification procedures for wastewater and } \\
\text { enrichment of trace heavy metals in natural waters prior to analysis. }\end{array}$} \\
\hline 2 & Ion exchange & $\begin{array}{l}\mathrm{Zn}, \\
\mathrm{Cd} \\
\mathrm{Cu} \\
\mathrm{Pb}\end{array}$ & 5 & 200ppm & ----- & $\begin{array}{l}\text { Distribution } \\
\text { coefficients }\end{array}$ & $\begin{array}{l}\text { Yi-Min Gao } \\
\text { Et al. (1995) }\end{array}$ \\
\hline \multicolumn{8}{|c|}{$\begin{array}{l}\text { Remarks } \\
\text { HISORB, a hybrid inorganic sorbent, can effectively remove low concentrations }(\mathrm{Mg} / \mathrm{l} \text { to rag/l) of } \\
\text { dissolved heavy metals in fixed-bed processes with an influent } \mathrm{pH} \text { as low as } 3.5 \text { from the } \\
\text { background of much higher concentrations of competing calcium and sodium ions. }\end{array}$} \\
\hline
\end{tabular}




\begin{tabular}{|c|c|c|c|c|c|c|c|}
\hline S.N. & $\begin{array}{l}\text { Method of } \\
\text { Removal of } \\
\text { heavy metal }\end{array}$ & Metal & pH & $\begin{array}{l}\text { Concent- } \\
\text { ration }\end{array}$ & $\begin{array}{c}\% \\
\text { Removal }\end{array}$ & Data & $\begin{array}{l}\text { Authors } \\
\text { Name }\end{array}$ \\
\hline 3 & $\begin{array}{l}\text { Biosorption } \\
\text { and ion } \\
\text { Exchange }\end{array}$ & $\begin{array}{l}\mathrm{Au} \\
\mathrm{Cd} \\
\mathrm{Co} \\
\mathrm{Cr} \\
\mathrm{Cu} \\
\mathrm{Hg} \\
\mathrm{Ni} \\
\mathrm{Pb} \\
\mathrm{Se} \\
\mathrm{Zn}\end{array}$ & $<6$ & $\begin{array}{l}10-100 \\
\text { ppm metal } \\
\text { solution }\end{array}$ & $>85 \%$ & $\begin{array}{l}\text { The range of } \\
\text { metals bound, } \\
\text { the effects of } \\
\mathrm{pH} \text {, } \\
\text { temperature, } \\
\text { contact time, } \\
\text { interference } \\
\text { by common } \\
\text { salts and the } \\
\text { effect of } \\
\text { multiple } \\
\text { cycles of } \\
\text { metal binding } \\
\text { and elution. }\end{array}$ & $\begin{array}{l}\text { Jack Z. Xie, } \\
\text { (1996) }\end{array}$ \\
\hline
\end{tabular}

\section{Remarks}

Biosorbents and chemically modified biosorbents were prepared and compared with commercial ion-exchange resins to determine their metal-binding capacity.

\begin{tabular}{|l|l|l|l|l|l|l|l|}
\hline 4 & $\begin{array}{l}\text { Fluidized bed } \\
\text { reactor; }\end{array}$ & Fe & 2 & $500 \mathrm{mg} / 1$ & $90 \%$ & -- & $\begin{array}{l}\text { Teruyuki } \\
\text { Umita } \\
(1996)\end{array}$ \\
\hline
\end{tabular}

\section{Remarks}

Hydraulic retention time can be decreased by using the fluidized bed reactor.

\begin{tabular}{|l|l|l|l|l|lr|l|l|}
\hline 5 & $\begin{array}{l}\text { Algal Biomass } \\
\text { Adsorption }\end{array}$ & $\begin{array}{l}\mathrm{Zn}, \\
\mathrm{Cu}, \\
\mathrm{Cd}\end{array}$ & $\begin{array}{l}2 \\
8\end{array}$ & $\begin{array}{l}500 \mathrm{mg} / \mathrm{lit} \\
\text { to } 3000 \\
\mathrm{mg} / \mathrm{lit}\end{array}$ & $\begin{array}{l}60 \\
85 \%\end{array}$ & to & $\begin{array}{l}\text { Effect of } \mathrm{pH}, \\
\text { Time } \\
\text { Concentration }\end{array}$ & $\begin{array}{l}\text { P.D. Rose } \\
\text { (1998) }\end{array}$ \\
\hline
\end{tabular}

\section{Remarks}

Utility of the waste stabilization pounding process, providing an established reactor technology for the treatment of large water volumes, and the feasibility of linking co-disposal of organic waste streams with AMD treatment.

\begin{tabular}{|l|l|l|l|l|l|l|l|}
\hline $\mathbf{6}$ & $\begin{array}{l}\text { Anaerobic } \\
\text { reactor with } \\
\text { mixture of rice } \\
\text { stalk, cow } \\
\begin{array}{l}\text { manure and } \\
\text { limestone }\end{array}\end{array}$ & $\begin{array}{l}\mathrm{Cd}, \mathrm{Pb}, \\
\mathrm{Al}, \mathrm{Fe}, \\
\mathrm{Mn} .\end{array}$ & 6 & $\begin{array}{l}70-126 \\
\mathrm{mg} / \mathrm{lit}\end{array}$ & $\begin{array}{l}98 \text { to } 100 \\
\%\end{array}$ & $\begin{array}{l}\text { Effect } \\
\text { Time }\end{array}$ & $\begin{array}{l}\text { Young- } \\
\text { Wook } \\
\text { Cheong } \\
(1998)\end{array}$ \\
\hline
\end{tabular}

\section{Remarks}

The reactor was successful in raising the $\mathrm{pH}$ and removing metals to over 95\%, except for $\mathrm{Mn}$. Maximum removal efficiencies of $\mathrm{Cu}, \mathrm{Zn}, \mathrm{Cd}, \mathrm{Pb}, \mathrm{Mn}$ and $\mathrm{Fe}$ were achieved when $\mathrm{pH}$ and $\mathrm{Eh}$ values were respectively 6 


\begin{tabular}{|l|l|l|l|l|l|l|l|}
\hline S.N. & $\begin{array}{c}\text { Method of } \\
\text { Removal of } \\
\text { heavy metal }\end{array}$ & Metal & $\mathbf{p H}$ & $\begin{array}{c}\text { Concent- } \\
\text { ration }\end{array}$ & $\begin{array}{c}\text { \% } \\
\text { Removal }\end{array}$ & Data & \multicolumn{1}{|c|}{$\begin{array}{c}\text { Authors } \\
\text { Name }\end{array}$} \\
\hline $\mathbf{7}$ & Bioremediation & Sulphate & $3-6$ & -- & $\begin{array}{l}14.4 \text { to } \\
26.7 \%\end{array}$ & $\begin{array}{l}\text { Effect } \\
\text { Time, } \\
\text { pH }\end{array}$ & $\begin{array}{l}\text { Phillip } \\
\text { Elliott } \\
(1998)\end{array}$ \\
\hline
\end{tabular}

Remarks

Sulfate-reducing bacteria (SRB) were capable of sulfate reduction and production of alkalinity at $\mathrm{pH}$ values as low as 3.25 .

\begin{tabular}{|l|l|l|l|l|l|l|l|}
\hline $\mathbf{8}$ & Continuously- & Fe & $\begin{array}{l}3.5 \\
6-100-250\end{array}$ & -- & Field & Carl S. \\
& stirred tank \\
& reactor & & $\begin{array}{l}6-\text { lit } \\
7\end{array}$ & & & determination & $\begin{array}{l}\text { Kirby } \\
(1998)\end{array}$ \\
\hline
\end{tabular}

\section{Remarks}

A field continuously-stirred tank reactor has been successfully used to determine Fe2+ oxidation rates in acid and alkaline mine drainage.

\begin{tabular}{|l|l|l|l|l|l|l|l|}
\hline $\mathbf{9}$ & $\begin{array}{l}\text { Microbial } \\
\text { activity }\end{array}$ & Fe & $4-5$ & $\begin{array}{l}300 \text { to } 92 \\
\mathrm{mg} / \mathrm{l},\end{array}$ & $32 \%$ & $\begin{array}{l}\text { Field } \\
\text { determination }\end{array}$ & $\begin{array}{l}\text { T. K. } \\
\text { Tsukamoto } \\
(1999)\end{array}$ \\
\hline
\end{tabular}

\section{Remarks}

Results indicate that methanol and lactate can be used effectively as reducing equivalents for restoring the activity of sulfate-reducing microorganisms in a laboratory anaerobic bioreactor containing spent substrate.

\begin{tabular}{|l|l|l|l|l|l|l|l|}
\hline $\mathbf{1 0}$ & 'Anoxic' & Al & & $34.3 \mathrm{mg} / \mathrm{l}$ & --- & Dissolved & E.I. Robbins \\
& limestone & Fe & 3.5 & & & \\
& drains (ALDs). & & -7 & & & $\begin{array}{l}\text { oxygen (DO), } \\
\text { pH values, } \\
\text { and water } \\
\text { table } \\
\text { elevation } \\
\text { Measurement } \\
\text { at different } \\
\text { depths }\end{array}$ & \\
& & & & & & & \\
& & & & & & & \\
& & & & & & & \\
\hline
\end{tabular}

\section{Remarks}

The very large variability of microbial populations on the homogenous substances tested in this research suggest that reactions with heterogeneous alkalinity-producing materials such as CCBs and FGDBs will be difficult to predict in advance of performing the actual field tests.

\begin{tabular}{|c|c|c|c|c|c|c|c|}
\hline 11 & Precipitation. & $\begin{array}{l}\mathrm{Fe} \\
\mathrm{Mn}\end{array}$ & $\begin{array}{l}1.6 \\
5 \\
\text { to } \\
12 . \\
5\end{array}$ & $\begin{array}{l}942 \mathrm{mg} / \mathrm{lit} \\
113 \mathrm{mg} / \mathrm{lit}\end{array}$ & $80-90 \%$ & $\begin{array}{l}\text { Sorption } \\
\text { Isotherm }\end{array}$ & \begin{tabular}{|l} 
D. Feng, \\
$(2000)$
\end{tabular} \\
\hline \multicolumn{8}{|c|}{ Remarks } \\
\hline
\end{tabular}




\begin{tabular}{|l|l|l|l|l|l|l|l|}
\hline S.N. & $\begin{array}{c}\text { Method of } \\
\text { Removal of } \\
\text { heavy metal }\end{array}$ & Metal & pH & $\begin{array}{c}\text { Concent- } \\
\text { ration }\end{array}$ & $\begin{array}{c}\text { \% } \\
\text { Removal }\end{array}$ & \multicolumn{1}{|c|}{ Data } & \multicolumn{1}{c|}{$\begin{array}{c}\text { Authors } \\
\text { Name }\end{array}$} \\
\hline $\mathbf{1 2}$ & Biosorption & $\begin{array}{l}\mathrm{Zn} \\
\mathrm{Cu}\end{array}$ & 3 & $700 \mathrm{mg} / \mathrm{lit}$ & $\begin{array}{l}74 \mathrm{mg} \\
\text { Uptake }\end{array}$ & $\begin{array}{l}\text { Langmuir } \\
\text { Isotherm }\end{array}$ & $\begin{array}{l}\text { Vivek } \\
\text { Utgikar } \\
(2000)\end{array}$ \\
\hline
\end{tabular}

\section{Remarks}

This study was confined to synthetic solutions of $\mathrm{Cu}(\mathrm{II})$ and/or $\mathrm{Zn}(\mathrm{II})$, closely corresponding to typical AMD compositions, and equilibrium uptake of the metals was observed at $\mathrm{pHs}$ of 3.0 and 3.8 .

\begin{tabular}{|l|l|l|l|l|l|l|l|l|}
\hline $\mathbf{1 3}$ & $\begin{array}{l}\text { Organic waste } \\
\text { material }\end{array}$ & $\begin{array}{l}\mathrm{Cu}, \\
\mathrm{Zn}\end{array}$ & 6.8 & $\begin{array}{l}50 \mathrm{ppm} \\
100 \mathrm{ppm}\end{array}$ & $85-90 \%$ & $\begin{array}{l}\text { Effect of } \\
\text { Time }\end{array}$ & $\begin{array}{l}\text { In Seop } \\
\text { Chang } \\
(2000)\end{array}$ \\
\hline
\end{tabular}

\section{Remarks}

Various waste materials could support bacterial sulfate reduction in packed bed reactors to treat acid mine drainage (AMD). A short-term experiment showed that raw biomass (OC) was less satisfactory for the purpose than biologically (SMC, SOS) or chemically (SWP) treated biomass.

\begin{tabular}{|l|l|l|l|l|l|l|l|}
\hline 14 & $\begin{array}{l}\text { Chemical } \\
\text { precipitation }\end{array}$ & Fe & 4.5 & $\begin{array}{l}194 \mathrm{ppm} \\
4.65 \mathrm{ppm}\end{array}$ & $80 \%$ & $\begin{array}{l}\text { Leaching } \\
\text { results }\end{array}$ & $\begin{array}{l}\text { Matthew M. } \\
\text { Matlock, } \\
(2002)\end{array}$ \\
\hline
\end{tabular}

\section{Remarks}

Current treatment processes for AMD, such as precipitation through neutralization and peroxide addition, have major disadvantages, including large doses of lime and peroxide and costly sludge disposal fees. The ability of BDET to reduce the concentration of the metal contaminates from the acidic waters directly from the mine emphasizes the compound's potential use as a treatment reagent. Due to the exceptional stability of the precipitates under oxidative and $\mathrm{pH}$ conditions, BDET can be utilized as an additive to reduce metal concentrations being discharged.

\begin{tabular}{|c|c|c|c|c|c|c|c|}
\hline 15 & $\begin{array}{ll}\text { Up flow } \\
\text { anaerobic } \\
\text { reactor }\end{array}$ & $\begin{array}{l}\mathrm{Fe}, \\
\mathrm{Al}, \\
\mathrm{Cu}, \\
\mathrm{Cd}\end{array}$ & $\begin{array}{l}6.3 \\
- \\
6.9\end{array}$ & $\begin{array}{l}279 \mathrm{mg} / \mathrm{lit} \\
13 \mathrm{mg} / \mathrm{lit} \\
68 \mathrm{mg} / \mathrm{lit} \\
56 \mathrm{mg} / \mathrm{lit}\end{array}$ & $99 \%$ & $\begin{array}{l}\text { Effect of } \\
\text { Time }\end{array}$ & $\begin{array}{l}\text { Hyun-Joon } \\
\text { La } \\
(2003)\end{array}$ \\
\hline
\end{tabular}

\section{Remarks}

The concentration of heavy metals in the effluent from the up flow anaerobic reactors was effectively removed.

\begin{tabular}{|l|l|l|l|l|l|l|l|}
\hline 16 & $\begin{array}{l}\text { Electrochemica } \\
1 \text { treatment }\end{array}$ & $\begin{array}{l}\mathrm{Fe} \\
\mathrm{Cu}\end{array}$ & $6-8$ & $\begin{array}{l}64 \mathrm{ppm} \\
58 \mathrm{ppm}\end{array}$ & $80-90 \%$ & $\begin{array}{l}\text { Proton } \\
\text { removal } \\
\text { efficiencies }\end{array}$ & $\begin{array}{l}\text { M.M.G. } \\
\text { Chartrand } \\
(2003)\end{array}$ \\
\hline
\end{tabular}

\section{Remarks}

Electrolysis of authentic AMD was successful in removing iron from solution, Development of an electrolytic technology for AMD remediation requires more work on the chronology of electrolysis, aeration, and sludge separation, and on cell design to optimize mass transfer and permit the in situ separation of the sludges formed when the original AMD contains significant quantities of $\mathrm{Fe}$ (III). 


\begin{tabular}{|l|l|l|l|l|l|l|l|}
\hline S.N. & $\begin{array}{c}\text { Method of } \\
\text { Removal of } \\
\text { heavy metal }\end{array}$ & Metal & pH & $\begin{array}{c}\text { Concent- } \\
\text { ration }\end{array}$ & $\begin{array}{c}\text { \% } \\
\text { Removal }\end{array}$ & Data & \multicolumn{1}{|c|}{$\begin{array}{c}\text { Authors } \\
\text { Name }\end{array}$} \\
\hline $\mathbf{1 7}$ & $\begin{array}{l}\text { Anaerobic } \\
\text { treatment; }\end{array}$ & Fe & 3.5 & $100 \mathrm{mg} / \mathrm{lit}$ & $93 \%$ & $\begin{array}{l}\text { Effect } \\
\text { Time }\end{array}$ & $\begin{array}{l}\text { T.K. } \\
\text { Tsukamoto } \\
(2004)\end{array}$ \\
\hline
\end{tabular}

\section{Remarks}

Ethanol and methanol were both successfully utilized to remove sulfate andiron in SRB column studies, although ethanol offers the advantage of a shortened acclimation time.

\begin{tabular}{|c|c|c|c|c|c|c|c|}
\hline 18 & Adsorption & $\begin{array}{l}\mathrm{Cu}, \\
\mathrm{Zn} \mathrm{Mn}\end{array}$ & -- & $\begin{array}{l}100 \text { to } 400 \\
\mathrm{mg} / \mathrm{l} .\end{array}$ & --- & $\begin{array}{l}\text { Langmuir, } \\
\text { Freundlich, } \\
\text { and Dubinin- } \\
\text { Kaganer- } \\
\text { Radushkevich } \\
\text { (DKR) } \\
\text { adsorption } \\
\text { isotherm data, }\end{array}$ & $\begin{array}{l}\text { E. Erdem } \\
\text { (2004) }\end{array}$ \\
\hline
\end{tabular}

\section{Remarks}

These results show that natural zeolite can be used effectively for the removal of metal cations from wastewater. This naturally occurring material provides a substitute for the use of activated carbon as adsorbent due to its availability and its low cost.

\begin{tabular}{|l|l|l|l|l|l|l|l|}
\hline 19 & Bioremediation & $\begin{array}{l}\text { Fe, } \\
\mathrm{Zn}, \\
\mathrm{Cu}\end{array}$ & $\begin{array}{l}2.3 \\
-6\end{array}$ & $\begin{array}{l}497 \mathrm{mg} / \mathrm{lit} \\
107 \mathrm{mg} / \mathrm{lit}\end{array}$ & $98 \%$ & Time study & $\begin{array}{l}\text { M. C. Costa } \\
\text { (2005) }\end{array}$ \\
\hline
\end{tabular}

\section{Remarks}

Further studies need to be carried out to control and maintain a stable sulfate removal for longer periods at values suitable for discharge on nature or for irrigation purposes.

\begin{tabular}{|c|c|c|c|c|c|c|c|}
\hline 20 & $\begin{array}{l}\text { Passive } \\
\text { Treatment }\end{array}$ & $\begin{array}{l}\mathrm{Fe} \\
\mathrm{Al} \\
\mathrm{Ni}\end{array}$ & 6.5 & $\begin{array}{l}\text { Fe } 2500 \\
\text { ppm } \\
\text { Al } 10.5 \\
\text { ppm Ni } \\
15 \text { ppm }\end{array}$ & $\begin{array}{l}\text { Fe } 99.95 \\
\% \\
\text { Al } 100 \% \\
\text { Ni } 85.7 \\
\%\end{array}$ & $\begin{array}{l}\text { Geo chemical } \\
\text { Modeling }\end{array}$ & $\begin{array}{l}\text { Louis R. } \\
\text { Bernier } \\
\text { (2005) }\end{array}$ \\
\hline
\end{tabular}

\section{Remarks}

The use of serpentinite to generate alkalinity in passive treatment systems design appears promising but more research, economic study and pilot testing is mandatory before full-scale implementation can be achieved. It is anticipated that perhaps in the near future, passive treatment using serpentinite will be implemented in the decontamination of mine effluents in areas where livestock drinking water is a rare resource and also contribute to the revalorization of asbestos (chrysotile) tailings if the economics are favorable. 


\begin{tabular}{|c|c|c|c|c|c|c|c|}
\hline S.N. & $\begin{array}{l}\text { Method of } \\
\text { Removal of } \\
\text { heavy metal }\end{array}$ & Metal & pH & $\begin{array}{l}\text { Concent- } \\
\text { ration }\end{array}$ & $\begin{array}{c}\% \\
\text { Removal }\end{array}$ & Data & $\begin{array}{c}\text { Authors } \\
\text { Name }\end{array}$ \\
\hline 21 & Precipitation & $\begin{array}{l}\mathrm{Fe} \\
\mathrm{Al}\end{array}$ & $\begin{array}{l}3.5 \\
- \\
4.0\end{array}$ & $\begin{array}{l}\mathrm{Fe} 172.5 \\
\mathrm{mg} / \mathrm{lit} \\
\mathrm{Al} \quad 88.6 \\
\mathrm{mg} / \mathrm{lit}\end{array}$ & $\begin{array}{lr}\text { Fe } & 98.6 \% \\
\mathrm{Al} & 97.2 \\
\% & \end{array}$ & Time Study & $\begin{array}{l}\text { Xinchao } \\
\text { Wei, } \\
\text { (2005) }\end{array}$ \\
\hline
\end{tabular}

\section{Remarks}

Simultaneous metal recovery and AMD treatment were achieved using a selective precipitation process based on solubility characteristics of the major and minor metals in the AMD.

\begin{tabular}{|l|l|l|l|l|l|l|l|}
\hline 22 & $\begin{array}{l}\text { Metal sulphide } \\
\text { precipitation }\end{array}$ & $\begin{array}{l}\mathrm{Zn} \\
\mathrm{Cu} \\
\mathrm{Fe}\end{array}$ & $4-6$ & $\begin{array}{l}\mathrm{Zn} 660 \\
\mathrm{mg} / \mathrm{l} \\
\mathrm{Cu} 19 \mathrm{mg} / \mathrm{l} \\
\mathrm{Fe} \mathrm{337}\end{array}$ & $\mathrm{Zn}$ & $\begin{array}{l}\text { Installation of } \\
\text { wastewater } \\
\text { treatment } \\
\text { plant }\end{array}$ & $\begin{array}{l}\text { Jacco L. } \\
\text { Huisman } \\
(2006)\end{array}$ \\
\hline
\end{tabular}

\section{Remarks}

The Thioteq technology is a new alternative for hydroxide precipitation based on safe and on-site hydrogen sulfide production. Biological reduction of elemental sulfur or sulfate produces low cost sulfide reagent that can be used effectively in water treatment for both environmental control and metal recovery. Commercial applications in industrial plants have shown the technology to be safe and robust.

\begin{tabular}{|c|c|c|c|c|c|c|c|}
\hline 23 & $\begin{array}{l}\text { Passive } \\
\text { biological } \\
\text { treatment }\end{array}$ & $\begin{array}{l}\mathrm{Fe} \\
\mathrm{Mn} \\
\mathrm{Cd} \\
\mathrm{Ni} \\
\mathrm{Zn}\end{array}$ & $\begin{array}{l}3.9 \\
- \\
4.2\end{array}$ & $\begin{array}{l}\mathrm{Fe} 1683 \\
\mathrm{mg} / \mathrm{l} \\
\mathrm{Mn} \\
\mathrm{mg} / \mathrm{l} \\
\mathrm{Cd} \\
\mathrm{mg} / \mathrm{l} \\
\mathrm{Ni} 16 \mathrm{mg} / \mathrm{l} \\
\mathrm{Zn} 18 \mathrm{mg} / \mathrm{l}\end{array}$ & $\begin{array}{l}\text { Fe } 100 \% \\
\text { Mn } 99 \% \\
\text { Cd } 99 \% \\
\text { Ni } 99 \% \\
\text { Zn } 94 \%\end{array}$ & $\begin{array}{l}\text { Geo chemical } \\
\text { modeling }\end{array}$ & $\begin{array}{l}\text { Gerald J. } \\
\text { Zagury } \\
\text { (2006) }\end{array}$ \\
\hline \multicolumn{8}{|c|}{$\begin{array}{l}\text { Remarks } \\
\text { The natural organic substrate mixtures (with and without formaldehyde) were successful in } \\
\text { promoting sulfate reduction and metal removal (94-99\%) but the lowest metal removal efficiency } \\
\text { was observed in the reactor containing poultry manure as a single carbon source. }\end{array}$} \\
\hline
\end{tabular}

\section{Conclusion}

Worldwide metal contamination of soil and water has severe impacts on environment and human health. Acid mine drainage is one of the most important sources of heavy metal environmental pollution. This review paper shows that the different removal techniques for heavy metal removal from acid mine drainage wastewater.

\section{REFERENCES}

[1] Lewis, M.E. and Clark, M. L.(1996): How does stream flow affect metals in the upper Arkansas River? - US Geological Survey Fact Sheet 226-296.

[2] Singer, P.C. and Stumm, W. (1970): Acidic mine drainage: the rate-determining step Science 167: 1121-1123. 
[3] Stumm, Werner and Morgan J.J.(1996): Aquatic Chemistry. - Wiley, New York.

[4] Gray, N.F. (1997): Environmental impact and remediation of acid mine drainage: a management problem - Environmental Geology 30(1/2): 62-71.

[5] B-W. Zhang, K. Fischer D. Bieniek and A. Kettrup (1993): Synthesis of amidoximecontaining modified starch and application for the removal of heavy metals - Reactive Polymers 20: 207-216.

[6] Yi-Min Gao L, Arup K. Sengupta and Dale Simpson (1995): A New Hybrid Inorganic Sorbent For Heavy Metals Removal - War. Res. Vol. 29, No. 9, p. 2195-2205.

[7] Jack Z. Xie, Hsiao-Lung Chang \& John J. Kilbane (1996): Removal and Recovery Of Metal Ions From Wastewater Using Biosorbents and Chemically Modified Biosorbents Bioresource Technology 57: 127-136.

[8] Teruyuki Umita (1996): Biological mine drainage treatment - Resources, Conservation and Recycling 16, 179-188.

[9] P.D. Rose, G.A. Boshoff, R.P. van Hille, L.C.M. Wallace, K.M. Dunn \& J.R. Duncan (1998): An integrated algal sulphate reducing high rate ponding process for the treatment of acid mine drainage wastewaters - Biodegradation 9: 247-257.

[10] Young-Wook Cheong, Jeong-Sik Min, Kwang-Soo Kwon (1998): Metal removal efficiencies of substrates for treating acid mine drainage of the Dalsung mine, South Korea - Journal of Geochemical Exploration 64, 147-152.

[11] Phillip Elliott1, Santo Ragusa and David Catcheside (1998): Growth Of Sulfate-Reducing Bacteria Under Acidic Conditions In An Upflow Anaerobic Bioreactor As A Treatment System For Acid Mine Drainage - Wat. Res. Vol. 32, No. 12, p. 3724-3730.

[12] Carl S. Kirby and Jennifer A., Elder Brady (1998): Field determination of Fe2+ oxidation rates in acid mine drainage using a continuously-stirred tank reactor- Applied Geochemistry, Vol. 13, No. 4, pp. 509-520.

[13] T. K. Tsukamoto And G. C. Miller (1999): Methanol As A Carbon Source For Microbiological Treatment Of Acid Mine Drainage- Wat. Res. Vol. 33, No. 6, p. 13651370.

[14] E.I.Robbinsa,C.A.Cravotta,C.E.Savelac,G.L.Nord Jr. (1999): Hydro- biogeochemical interactions in 'anoxic' limestone drains for neutralization of acidic mine drainage - Fuel, 78, 259-270.

[15] D. Feng, C. Aldrich And H. Tan (2000): Treatment Of Acid Mine Water By Use Of Heavy Metal Precipitation And Ion Exchange - Minerals Engineering, Vol. 13, No. 6, p. 623-642.

[16] Vivek Utgikar, Bor-Yann Chena, 1, Henry H. Tabaka, Dollo. F. Bishopa, Rakesh Govind (2000): Treatment of acid mine drainage: I. Equilibrium biosorption of zinc and copper on non-viable activated sludge- International Biodeterioration \& Biodegradation ,46, 1928.

[17] In Seop Chang, Pyong Kyun Shin And Byung Hong Kim (2000): Biological Treatment Of Acid Mine Drainage Under Sulphate-Reducing Conditions With Solid Waste Materials As Substrate - Wat. Res. Vol. 34, No. 4, p. 1269-1277.

[18] Matthew M. Matlock, Brock S. Howerton, David A. Atwood (2002): Chemical precipitation of heavy metals from acid mine drainage- Water Research 36 4757-4764

[19] Hyun-Joon La, Kyoung-Ho Kim, Zhe-Xue Quan Young-Gyun Cho \& Sung-Taik Lee (2003): Enhancement Of Sulfate Reduction Activity Using Granular Sludge In Anaerobic Treatment Of Acid Mine Drainage - Biotechnology Letters 25: 503-508.

[20] M.M.G. Chartrand and N.J. Bunce (2003): Electrochemical Remediation Of Acid Mine Drainage - Journal Of Applied Electrochemistry 33: 259-264.

[21] T.K. Tsukamoto,H.A. Killion, G.C. Miller (2004): Column experiments for microbiological treatment of acid mine drainage: low-temperature, low-pH and matrix investigations- Water Research 38: 1405-1418.

[22] E. Erdem a, N. Karapinar b, R. Donat (2004): The removal of heavy metal cations by natural zeolites - Journal of Colloid and Interface Science 280: 309-314. 
[23] M. C. Costa1, and J. C. Duarte (2005): Bioremediation Of Acid Mine Drainage Using Acidic Soil And Organic wastes For Promoting Sulphate-Reducing Bacteria Activity On A Column Reactor - Water, Air, And Soil Pollution, 165: 325-345.

[24] Louis R. Bernier (2005): The potential use of serpentinite in the passive treatment of acid mine drainage: batch experiments- Environ Geol 47, 670-684.

[25] Xinchao Wei, Roger C. Viadero, Jr., and Karen M. Buzby (2005): Recovery Of Iron And Aluminum From Acid Mine Drainage By Selective Precipitation - Environmental Engineering Science Volume 22, Number 6, 745-755.

[26] Jacco L. Huisman , Gerard Schouten, Carl Schultz (2006): Biologically produced sulphide for purification of process streams, effluent treatment and recovery of metals in the metal and mining industry - Hydrometallurgy (in press).

[27] Gerald J. Zagury, Viktors I. Kulnieks, Carmen M. Neculita (2006): Characterization and reactivity assessment of organic substrates for sulphate-reducing bacteria in acid mine drainage treatment - Chemosphere (in press). 